\title{
Living up to America's Values: Reforming the U.S. Detention System for Asylum Seekers
}

\author{
ELEANOR ACER
}

\section{Abstract}

The U.S. detention system for asylum seekers is fundamentally flawed. These flaws reflect an underlying lack of fairness that is inconsistent with international law and with U.S. traditions of fairness. For instance, the initial determination to detain an asylum seeker is not the result of an individualized determination, but is instead mandatory. Subsequent parole decisions are entrusted to the INS, which is the detaining authority, rather than to an independent authority. In short, the system lacks the kinds of safeguards necessary to promote due process and to guard against unfair and arbitrary detention. Reform is possible. The detention system for asylum seekers can be improved so that it is consistent with the values of fairness that the United States strives to meet.

\section{Résumé}

Le système américain de détention des demandeurs d'asile souffre de lacunes fondamentales. Ces lacunes reflètent un manque d'équité sous-jacent qui est incompatible avec le droit international et les traditions américaines d'équité. Par exemple, la décision initiale de détenir un demandeur d'asile n'est pas une décision individualisée, mais est en fait obligatoire. Les décisions de libérations conditionnelles sont laissées à la discrétion $d u$ service d'immigration et de naturalisation (INS) - qui est lui-même l'autorité détenant les prisonniers - plutôt qu'à une autorité indépendante. Bref, le système n'est pas doté des garanties nécessaires pour promouvoir le respect des procédures et protéger les intéressés contre la déten- tion injuste et arbitraire. La réforme du système est possible. Le système de détention des demandeurs d'asile peut être amélioré afin de le rendre compatible avec les valeurs d'équité auxquelles les États-Unis s'efforcent de se conformer.

\section{Introduction}

After they took my statement, they put me in handcuffs. I was very surprised by this. I remember asking one of the officers whether it was a crime to ask for asylum. He replied: "This is the law." After that they brought me to a detention center in New Jersey. I was even more surprised to be taken to a place where they took away my clothes and gave me the uniform of a prisoner.

1 hese are the words of a torture survivor who was detained in the U.S. for seven months while he waited for his asylum claim to be granted. He later explained:

I knew that asking for asylum was a right under international law. In my country, when I used to think about international law and human rights, the United States was the first country I associated with those ideals. What I experienced when I arrived here did not correspond to the vision that those outside of the United States have of this country. ${ }^{1}$

Whether they are Christians fleeing religious persecution in Sudan, torture survivors from Iraq, pro-democracy activists fleeing a repressive regime in Congo, victims of coercive population control policies in China, rape survi- 
vors from minority clans in Somalia, or gay men attacked in Colombia because of their sexual orientation, those who flee to the United States arrive with the belief that they have finally reached a place where they will be safe, free, and treated fairly. For those who seek asylum at the U.S. borders and airports, the welcome they receive - handcuffs, shackles and mandatory detention - can be a devastating surprise.

The hurdles facing these asylum seekers are truly daunting. Summary "expedited removal" procedures, "mandatory detention," inconsistent parole practices, lack of government-funded legal representation, and language and translations difficulties are among the many hurdles arriving asylum seekers must navigate in their efforts to secure refuge in the United States.

In the wake of the tragic events of September 11, these hurdles have only multiplied. While none of the perpetrators of the September 11 attacks were asylum seekers or refugees, various measures taken by the U.S. government that affect non-citizens in general will necessarily affect those who seek asylum in the U.S. At the same time, new concerns have arisen regarding the use by the U.S. Immigration and Naturalization Service (INS) of its detention and parole authority with respect to asylum seekers - with reports of discriminatory parole policies aimed at asylum seekers from Arab or Muslim backgrounds, and, as the situation in Haiti has deteriorated, at asylum seekers who have fled to the U.S. from Haiti.

The U.S. detention system for asylum seekers is vulnerable to these and other abuses in part because of some fundamental flaws in the system. The initial determination to detain an asylum seeker is not the result of an individualized determination, but is instead mandatory. Subsequent parole decisions are entrusted to the INS, which is the detaining authority, rather than to an independent authority. The parole criteria for asylum seekers are set forth in guidelines rather than in enforceable regulations. The system does not provide for an appeal of parole denials to an independent judicial authority. In short, the system lacks the kinds of safeguards necessary to promote due process and to guard against unfair and arbitrary detention. Reform is possible. The detention system for asylum seekers can be improved so that it is consistent with the values of fairness that the United States strives to meet.

\section{The U.S. System for Detaining Asylum Seekers}

In 1980, the United States reversed its nearly thirty-year policy of detaining only those non-citizens who were considered a danger to the community or flight risks. ${ }^{2}$ Instead, it began a policy of detaining those who sought to enter the U.S. with false or invalid documents-a situation which faces many genuine refugees since they may be unable to obtain travel documents from the governments that persecute them or may, like the Kosovo refugees, be stripped of their documents by their persecutors. ${ }^{3}$

This detention regime has been codified in the Illegal Immigration Reform and Immigrant Responsibility Act of 1996 (IIRIRA or the "1996 immigration law"), which requires the "mandatory detention" of various classes of noncitizens. The 1996 immigration law's "expedited removal" provisions require "mandatory detention" of all asylum seekers who arrive in the United States without valid documents, until they pass out of the "expedited removal" process by establishing a "credible fear of persecution" in an interview with an INS asylum officer or a subsequent review by an immigration judge. 4 The credible fear standard is met if there is a "significant possibility, taking into account the credibility of the statements made by the alien in support of the alien's claim and such other facts as are known to the officer, that the alien could establish eligibility for asylum...."

The expedited removal process itself is wrought with serious flaws. It entrusts the decision to deport an individual who arrives with false or invalid travel documents to an immigration inspections officer, instead of a trained immigration judge. While asylum seekers are not supposed to be deported unless they are first given a chance to prove to an INS asylum officer that they have a "credible fear of persecution," mistakes have been made. ${ }^{6}$ The press and human rights organizations have documented instances of mistaken expedited removal determinations and other abuses relating to the conduct of the expedited removal process. Mistakes are indeed inevitable given the summary nature of the process and its lack of crucial safeguards. ${ }^{7}$

Shortly before the expedited removal provisions went into effect in April 1997, the INS increased its detention space and opened two large detention facilities to house asylum seekers subject to the expedited removal/mandatory detention provisions. These two facilities, both run by private contractors, are the two-hundred-bed facility near JFK International Airport in Queens, New York, which is run by Wackenhut Corrections Corporation, and the threehundred-bed facility near Newark International Airport in Elizabeth, New Jersey, which is run by Correction Corporation of America. Asylum seekers are also held in other facilities across the country, including county and local jails.

While the expedited removal provisions of the 1996 immigration law require the detention of asylum seekers during the expedited removal process, they do not prohibit parole once asylum seekers have established a credible fear of persecution and are therefore no longer subject to expedited removal proceedings. ${ }^{8}$ The authority to parole arriv- 
ing asylum seekers, however, is entrusted to the detaining authority, the INS. If the INS denies parole, that decision cannot be appealed to an independent or judicial authority. While immigration judges can review INS custody and bond decisions with respect to various other categories of non-citizens, ${ }^{9}$ immigration judges are precluded from reviewing issues relating to the detention of "arriving" aliens, a category which includes all arriving asylum seekers. ${ }^{10}$

After the passage of the 1996 immigration law, INS headquarters repeatedly advised local INS districts that asylum seekers who have established a credible fear of persecution are eligible for parole, and INS issued memoranda setting forth guidelines regarding the parole of asylum seekers. In December 1997, the INS issued guidelines which specifically confirmed that "[p] arole is a viable option and should be considered for aliens who meet the credible fear standard, can establish identity and community ties, and are not subject to any possible bars to asylum involving violence or misconduct." 11 These guidelines were derived from the APSO (Asylum Pre-Screening Officer) Parole Program of the early 1990s. ${ }^{12}$ In October 1998, another set of INS guidelines stated that "[a]lthough parole is discretionary in all cases where it is available, it is INS policy to favor release of aliens found to have credible fear of persecution, provided that they do not pose a risk of flight or danger to the community." 13

While the INS has issued guidelines regarding the parole of asylum seekers, it has refused to issue regulations specifically addressing the parole of asylum seekers. In January 1996, the Lawyers Committee for Human Rights filed a Petition for Rulemaking, requesting that the INS issue regulations codifying its parole guidelines for asylum seekers. In its Petition, the Lawyers Committee addressed in detail the deficiencies in the implementation of the INS parole program for asylum seekers and stressed the need for regulations to ensure that the parole program would be implemented properly and consistently. ${ }^{14}$

For years, human rights organizations, refugee advocates, and the press have documented the inconsistencies in parole practices from one INS district to another, and have documented cases of individual asylum seekers who have been detained for years while awaiting resolution of their asylum cases. ${ }^{15}$

These problems are so acute that the Department of Justice and the INS, in December 2000, issued a regulation to "clarify" that the INS Commissioner, other officials at INS headquarters, and regional directors are authorized to grant parole from INS custody. ${ }^{16}$ Some INS district directors had apparently maintained that INS headquarters did not have the authority to interfere in their parole determinations. ${ }^{17}$ The fact that the Department of Justice had to take the step of issuing a regulation simply to ensure that INS district directors understood that the INS Commissioner had authority over their parole determinations underscores how deeply rooted these problems are in the asylum detention system.

While the December 2000 regulatory change was a positive step, this change has not led to any significant improvement in the asylum detention system. In fact, as discussed below, the fundamental flaws in the system have made it more vulnerable to abuse in the post-September 11 climate. Significantly, the revised rule, in and of itself, does not fix many of the underlying problems in the U.S. system for detaining arriving asylum seekers. For instance, it did not codify the guidelines for parole of asylum seekers into enforceable regulations. It also left parole decisions in the hands of the INS rather than entrusting these decisions to independent adjudicators.

\section{The Impact of the Detention Regime}

At any time, the U.S. government detains about twenty-two thousand non-citizens in INS detention facilities and jails, and it has been estimated that several thousand of those detainees are asylum seekers. ${ }^{18}$ Precise statistical information about asylum seekers, including the number of asylum seekers in detention, has long been difficult to obtain from the INS. For years, in fact, the INS has been unable to regularly provide statistical information relating to detained asylum seekers - even in the face of a federal statute requiring the INS to report these numbers to Congress. ${ }^{19}$

While there may be a dearth of statistical information, there is no dearth of individual stories. The press, human rights groups, and faith-based organizations have detailed the harsh impact of detention on individual asylum seekers. ${ }^{20}$ Particularly disturbing are the reports of lengthy detentions - sometimes lasting for several years. ${ }^{21}$ In researching the immigration detention system, the Dallas Morning News obtained statistics revealing that over 851 non-citizens in detention had been detained for over three years, and that 361 of these detainees were asylum seekers or other detainees who had not been convicted of any crime. ${ }^{22}$ The San Jose Mercury News, in the course of conducting interviews for its award-winning series on asylum, gathered information relating to about fifty-six asylum seekers who were detained for over one year before being granted asylum. ${ }^{23}$

The impact of detention on children has been the subject of increasing scrutiny over the last two years. ${ }^{24}$ The intense public interest in the case of Elian Gonzalez, a young Cuban boy who was paroled to relatives in Miami, helped to highlight concerns about the INS's detention and treatment of so many other children. ${ }^{25}$ About 5000 children have been reported to be in INS custody; many are held in juvenile 
jails and shelters. ${ }^{26}$ Children have also been detained in adult jails and detention facilities when the INS has mistakenly concluded that they are adults based on dental examinations - a procedure that has been widely criticized by medical experts and is no longer relied upon even by the U.S. State Department. ${ }^{27}$

Detention can be particularly difficult for the many asylum seekers who are survivors of rape, torture and other traumatic experiences. Medical experts have documented the fact that many refugees often suffer from post-traumatic stress disorder, major depression, or other illnesses. ${ }^{28}$ As one expert explained: "For someone who's been tortured and locked up in a cell as a political prisoner in their native countries ... the experience of being locked up here again can trigger panic attacks, flashbacks." 29

The costs of detention are tremendous. The INS detention and removal budget is now over $\$ 1$ billion. The INS reportedly spends an average of $\$ 78$ a day to detain a non-citizen. To detain an asylum seeker through his or her initial hearing before an immigration judge has been reported to cost, on the average, $\$ 7259$ for a single asylum seeker. This does not include the substantial expense of additional detention while any appeals are pending. It has been estimated that detaining asylum seekers costs taxpayers at least $\$ 42.7$ million per year. ${ }^{30}$

Additional challenges in the wake of September 11 In the wake of the September 11 attacks on the World Trade Center and the Pentagon, the difficulties facing asylum seekers in the U.S. have multiplied. While none of the perpetrators of the September 11 attacks were asylum seekers or refugees, the U.S. Department of Justice has instituted a number of measures that apply more broadly to all non-citizens but will negatively affect asylum seekers as well. Of great concern is the Department of Justice's proposal to drastically restrict the ability of the Board of Immigration Appeals to review decisions of immigration judges. ${ }^{31}$ The proposal seeks to eliminate the Board's de novo factual review in most cases and encourages the issuance of summary orders. Advocates for refugees have roundly criticized the proposal as it would severely undermine the asylum appellate process and deprive asylum seekers of a meaningful appellate review. ${ }^{32}$

On December 3, 2001, the U.S. and Canada announced, in the context of broader co-operation on a range of border and security issues, that they will revive discussions on a safe third-country exception to the right to apply for asylum. According to the joint statement issued by the U.S. and Canada, the safe third-country arrangement "would limit the access of asylum seekers, under appropriate circumstances, to the system of only one of the two countries." ${ }^{33}$ Such an arrangement could further limit the ability of asylum seekers who transit through the U.S. before seeking asylum in Canada (including asylum seekers who are detained in the U.S.) to access the Canadian asylum system even if their only family or contacts are in Canada. ${ }^{34}$

Also troubling are a series of regulations issued by the Department of Justice in late September and October 2001 which expand INS detention authority. One of these regulations authorizes an increase in the time to charge detained non-citizens to forty-eight hours and, in cases of undefined "extraordinary" circumstances or an "emergency," to some unspecified greater "reasonable" period of time. As a result, the INS has been given the power to detain a non-citizen who has committed no crime - and who is not in any way suspected to be a danger to anyone - for an unspecified period of time without even charging the non-citizen with an immigration violation. ${ }^{35} \mathrm{~A}$ second new regulation allows an INS attorney to, in essence, overrule an immigration judge's decision to release a detainee on bond. There is no requirement that the individual be suspected of a crime or of terrorist activity. ${ }^{36}$

With respect to the over 1,100 non-citizens detained in the wave of arrests following September 11, the press and human right organizations have documented a range of disturbing abuses including lengthy detentions without charges, denial of access to counsel, the conduct of secret hearings, and abusive treatment. ${ }^{37}$ These detainees are overwhelmingly non-citizen men of Arab or Muslim background who are being held or have already been deported based on immigration violations. While the vast majority of these individuals are not asylum seekers, a few refugees have been caught up in this wave of detentions. ${ }^{38}$

At the same time, the INS's handling of the asylum detention system has also raised concerns. Parole for asylum seekers, already restrictive in some areas of the U.S., seems to have become even more restrictive in the wake of September 11. This may be the result of a memorandum issued by the INS in November 2001, which states that "[d]uring the nation's heightened security alert and until further notice," District Director (or other specified) approval is required in order to parole aliens or take certain other actions. The memorandum states that: "discretion should be applied only in cases where inadmissibility is technical in nature (i.e., documentary or paperwork deficiencies), or where the national interest, law enforcement interests, or compelling humanitarian circumstances require the subject's entry in the United States ...." The memorandum, however, also states that the guidance does not change existing statutory and regulatory standards for parole. ${ }^{39}$

Particularly troubling are reports of discriminatory parole practices. The press has documented cases in which asylum seekers from Arab or Muslim backgrounds, who 
would previously have been paroled prior to September 11, have been denied parole. For instance, two Christian women who fled Iraq were denied parole in Miami, even though one of the women has strong community ties, specifically her U.S. citizen sister and U.S. legal permanent resident mother. Another young man, whose family is also Christian, fled forced conscription by the Iraqi regime. $\mathrm{He}$ too was denied parole even though he had a U.S. citizen brother and parents who also live in the U.S. ${ }^{40}$

Additional charges of discriminatory parole practices have been leveled with respect to Haitian asylum seekers. In early December 2001, a boat bearing nearly 200 Haitian men, women and children arrived off the coast of Florida. In response, the INS has instituted a policy of denying parole to Haitian asylum seekers. A lawsuit filed in March 2002 alleges that the policy discriminates against Haitians based on their race and nationality and violates the U.S. Constitution's guarantees of due process and equal protection. The INS has admitted that this policy is designed to deter other Haitian asylum seekers from fleeing to the U.S. ${ }^{41}$

The impact of these various policy and regulatory changes on asylum seekers is significant and will become even more significant as the Department of Justice moves forward with additional changes. These actions, taken by the INS and the Department of Justice in the wake of the September 11 attacks, are particularly troubling in that these actions are undermining a system that protects people who are victims of horrific human rights abuses.

Compounding this irony is the fact that the asylum system is replete with rigorous safeguards designed to flag and exclude those who are a danger. The fingerprints of every asylum applicant are taken and sent to the FBI for a security check. The names and birth dates of applicants are also checked against various FBI, State Department, and CIA databases. ${ }^{42}$ Anyone who presents a risk to U.S. security is barred from asylum, as are those who have persecuted others or committed serious crimes. ${ }^{43}$ The INS regulations and the INS parole guidelines specifically prohibit the parole of anyone who would be barred from asylum or would present a risk to the community. ${ }^{44}$

The Lack of Fairness in the Asylum Detention System There are a number of fundamental flaws in the U.S. asylum detention system. These flaws reflect an underlying lack of fairness that is inconsistent with international law and standards and with U.S. traditions of fairness and due process.

- Detention is mandatory for all asylum seekers who arrive without valid documents.

Genuine refugees often have no choice but to flee to safety by using false or invalid travel documents. Many asylum seekers - from the Jews who fled Nazi persecution using false travel documents to the ethnic Albanians who were stripped of their documents as they fled Kosovo - have no choice but to flee to safety without valid travel documents. ${ }^{45}$ For instance, one client of the Lawyers Committee, a young Afghan woman who was persecuted by the Taliban because she ran a school for young girls, purposefully left her identification documents behind, knowing that if other Taliban forces intercepted her as she fled her country, her danger would be multiplied if they were to learn her true identity. ${ }^{46}$ Ironically, even asylum seekers who arrive on their own valid passports and visas that were actually issued to them by the United States government are considered to have "invalid" travel documents and are subject to mandatory detention if they honestly inform U.S. officials upon their arrival that they are planning to apply for asylum. ${ }^{47}$

Under the U.S. expedited removal law, detention is mandatory for arriving asylum seekers who arrive without valid travel documents, and as there is no valid visa for seeking asylum in the U.S., any arriving asylum seeker is generally considered to have invalid travel documents. The initial decision to detain is automatic under the law, not providing for individualized determinations of who should and should not be detained.

This mandatory or automatic approach to detention is inconsistent with international law and guidelines, which limit restrictions on movement to cases in which such restrictions are necessary. Article 31 of the 1951 Refugee Convention generally exempts refugees from being punished because of their illegal entry or presence and provides that states shall not place restrictions on the movements of refugees other than those that are necessary. ${ }^{48}$ In order to ensure consistency with Article 31, the Detention Guidelines issued by the United Nations High Commissioner for Refugees (UNHCR), provide that: "[D]etention should only be resorted to in cases of necessity. The detention of asylum-seekers who come 'directly' in an irregular manner should, therefore, not be automatic nor should it be unduly prolonged." Indeed, the Executive Committee of the UNHCR, of which the United States is a member, has stated in Conclusion 44, that detention of asylum seekers "should normally be avoided." ${ }^{49}$

\section{- The U.S. has failed to issue regulations specifically addressing parole of asylum seekers; instead the criteria are set forth in unenforceable guidelines.} As detailed above, the INS has refused to issue regulations setting forth the criteria for paroling asylum seekers. Instead, these criteria - which include the establishment of identity, the existence of community ties, the satisfaction of the credible fear standard, the absence of bars to asylum involving 
violence or misconduct, and that the individual does not pose a danger to the community - are detailed in a series of memoranda which the INS has labeled as "guidelines." 50

As a result, the INS and its District Directors have, in effect, been left free to ignore the guidelines. And they do. Asylum seekers who satisfy the criteria have been denied parole. Parole policies have varied widely between INS Districts, as have parole rates.51 Some individual INS Districts have radically changed their parole policies, disregarding the guidelines, and choosing instead to refuse to parole asylum seekers in response to specific goals of deterring asylum seekers. For instance, the New Jersey INS changed its parole policy in 1998, admitting that its detention policies were premised on deterrence objectives. Its parole rate dropped dramatically: from a parole rate that was reportedly about 89 percent to a rate of about 21 percent. ${ }^{52}$ Most recently, the Florida INS district, which had previously paroled eligible Haitian asylum seekers, began to refuse to parole Haitian asylum seekers in an attempt to deter additional Haitian asylum seekers from coming to the United States..$^{53}$

Thus, parole determinations in the U.S. are often based not on whether individual asylum seekers satisfy the criteria specified in the INS parole guidelines, but instead on vagaries such as the airport the asylum seeker arrived at, the availability of bed space in the area, and the particular policies of individual INS District Directors. These disparities, as illustrated by the following excerpt from a Detention Watch Network newsletter, can dramatically affect the experiences of individual refugees:

Adams Bao and Hua Zhen Chen are both seeking asylum in the United States. But their experiences in the asylum process have been radically different. Why? One reason is a surprisingly arbitrary one: Adams' boat docked in New Orleans and Chen's plane landed in Virginia.

Adams fled Sierra Leone, where his father and sister were killed in the civil war. He had access to one of the few alternatives to detention in this country. As a result, while he awaits his asylum hearing Adams is working to support himself and mastering rare glass-blowing skills in New Orleans.

Chen was not so fortunate. After arriving at Dulles Airport in December 1999, she spent 20 months detained in five different jails in Virginia before INS finally released her in late July. A native of China, Chen suffered the forced abortion of her second child and fled to the United States to avoid sterilization and imprisonment. During those 20 months INS denied her parole three times even though Chen had family in Ohio willing to take her in. ${ }^{54}$
Such a process is plainly arbitrary. Detention determinations that are based not on clear rules, but instead on ever-shifting factors that are not established by law, are arbitrary by definition. The International Covenant on Civil and Political Rights (ICCPR), to which the U.S. is a party, specifically provides in Article 9(1) that: "No one shall be deprived of his liberty except on such grounds and in accordance with such procedures as are established by law." 55

- The initial parole decisions are made by INS detention officers who are ill-trained and ill-equipped to make these determinations.

Under U.S. regulations, the decision to parole an asylum seeker is entrusted to local INS District Directors. In practice, it is typically an individual INS detention officer who makes the initial assessment and recommendation on release. These officers are not adequately trained to make these determinations. They are officers whose primary responsibility is enforcement of the immigration laws, rather than adjudication. Also, unlike the specially trained INS asylum officers, these officers do not receive extensive training in asylum law or in the human rights situations of the various countries from which asylum seekers flee. Compounding this difficulty is the fact that there are significant career, budgetary, and other considerations that create incentives for local INS district officials not to release asylum seekers from detention. ${ }^{56}$

- Neither initial detention determinations nor reviews of parole denials are conducted by an independent authority. The INS, in effect, is judge and jailer with respect to parole decisions.

Under U.S. procedures, the decision of whether or not to parole an arriving asylum seeker is entrusted to the INS, the same authority that is charged with seeking to detain and deport the individual. The INS, in effect, acts as both judge and jailer with respect to parole decisions. And, as discussed above, when the INS denies parole to an arriving asylum seeker, the law does not provide for an appeal of this determination to an independent or judicial authority. ${ }^{57}$

This lack of meaningful independent review of decisions to detain asylum seekers is a clear violation of U.S. obligations under international law. Article 9(4) of the ICCPR provides that:

Anyone who is deprived of his liberty by arrest or detention shall be entitled to take proceedings before a court, in order that the court may, decide without delay on the lawfulness of his detention and order his release if the detention is not lawful. ${ }^{58}$ 
This provision applies to all detainees, including immigration detainees. ${ }^{59}$ The UN Human Rights Committee, in its decision in Torres v. Finland, ${ }^{60}$ explained that Article 9(4) of the ICCPR "envisages that the legality of detention will be determined by a court so as to ensure a higher degree of objectivity and independence...." In the case of $A$ v. Australia, the UN Human Rights Committee, in finding that a limited court review did not satisfy the requirements of Article 9(4), emphasized that court review "must include the possibility of ordering release, is not limited to mere compliance of the detention with domestic law," and must be "in its effects, real and not merely formal." ${ }^{61}$ The UNHCR Detention Guidelines call for procedural guarantees, when a decision to detain is made, including "automatic review before a judicial or administrative body independent of the detaining authorities." ${ }^{\prime 2}$

- U.S. law does not provide a limit on the length of time asylum seekers may be detained.

In the United States, arriving asylum seekers are regularly held in detention facilities or jails for months, and sometimes for years. The INS does not regularly release information about lengthy detention of asylum seekers. In fact, as noted above, while the INS has repeatedly failed to provide statistical information relating to detained asylum seekers, the press and human rights groups have documented numerous examples of asylum seekers who have been detained for lengthy periods of time. ${ }^{63}$

Neither U.S. statutes nor regulations specify a limit on the length of time an asylum seeker may be detained while his or her removal and asylum proceedings are pending. But the reasoning of a recent U.S. Supreme Court decision, which examined a statute governing the detention and release of aliens who had already been ordered removed, makes clear that indefinite detention raises serious due process concerns under the U.S. Constitution. In Zadvydas v. Davis, the Supreme Court ruled that the indefinite detention of aliens who had been admitted to the United States and subsequently ordered removed would raise serious concerns under the U.S. Constitution. ${ }^{64}$ The Court construed the statute at issue to contain an implicit reasonable time limitation, which citing to Congressional intent, the Court determined to generally be a period of six months. ${ }^{65}$

The Zadvydas case involved non-citizens who had been admitted to the United States as opposed to non-citizens who had not yet gained admission. The latter category would include arriving asylum seekers who are deemed to have not yet been admitted. The Court, noting that its decision involved individuals who had been admitted to the U.S., concluded that it did not need to examine the question of the continued authority of the doctrine that has drawn a legal distinction between non-citizens who were afforded constitutional rights because they had "entered" the U.S. and those non-citizens who have traditionally been afforded less rights because they were deemed not to have entered the U.S. The continued viability of this legal fiction has been questioned by some legal experts. ${ }^{66}$ The Department of Justice, citing this distinction, has refused to recognize the applicability of the Zadvydas decision to the detention of arriving non-citizens who have not yet been admitted to the U.S. ${ }^{67}$

The absence of a limit on the length of detention is problematic under international standards as well. In $A \mathrm{v}$. Australia, the UN Human Rights Committee recognized that "every decision to keep a person in detention should be open to review periodically so that the grounds justifying detention can be assessed." 68 The UN Working Group on Arbitrary Detention, in its Deliberation No. 5, has set forth a number of guarantees to be considered in assessing whether an asylum seeker's deprivation of liberty is arbitrary under international law. One of these guarantees provides that: "A maximum period should be set by law and the custody may in no case be unlimited or of excessive length." 69

\section{- The U.S. does not fund legal representation for indigent asylum seekers.}

The U.S. government, unlike some European and other governments, does not provide funding for legal representation of asylum seekers. A study conducted by the Georgetown University Institute for the Study of International Migration, which analyzed U.S. government statistics, revealed that asylum seekers are four to six times more likely to be granted asylum when they are represented. The Georgetown analysis also revealed that in immigration court, more than one out of three asylum seekers lacks representation. For detained asylum seekers, the situation is even worse - more than twice as many detained asylum seekers lack representation when compared with non-detained asylum seekers in defensive proceedings. ${ }^{70}$ This is no surprise as detained asylum seekers typically have less access to legal representation, particularly as some are detained in remote areas that are far from legal service providers.

At the same time, detained asylum seekers face greater burdens in attempting to prove their cases. The ability of a detained asylum seeker to gather documentation and locate and communicate with witnesses who could corroborate the facts of her claim is severely hampered by the very fact of detention. Although telephones are available in detention, she may not be able to afford a calling card or may be limited to collect calls, which some individuals and non-profit organizations may not accept. The telephones are routinely located 
in large "pod" or "dorm" areas that may hold scores of other detainees, so that no meaningful degree of privacy is available to make calls to counsel or potential witnesses. ${ }^{71}$ In addition, detained asylum seekers often have little or no meaningful access to legal materials or country condition reports that are essential to the preparation of their cases. ${ }^{72}$

- The United States has not implemented nationwide alternatives to detention for asylum seekers.

There are a number of successful models of alternatives to detention that have been tested in the United States. These models have demonstrated high appearance rates for asylum seekers - ranging from 93 per cent to 96 per cent - and significant cost savings for the U.S. government.

The most comprehensive model alternative program was a pilot project conducted by the Vera Institute of Justice in contract with the INS. In this pilot program, which was called the Appearance Assistance Program, the Vera Institute supervised the release of asylum seekers and other non-citizens. In order to be released to supervision, participants were required to report regularly in person and by phone. Their whereabouts were monitored. Participants were also provided with information about the consequences of failing to comply with U.S. immigration laws. Participants in a less intensive program were given reminders of court hearings and were provided with legal information, and referrals to lawyers, and other services. ${ }^{73}$

The Vera Institute pilot project reported a very high appearance rate of 93 per cent for asylum seekers released through its appearance assistance program, and also concluded that the cost of supervision was 55 per cent less than the cost of detention. ${ }^{74}$ In concluding that supervised release is more cost effective than detention for asylum seekers, the Vera Institute noted that " $i] \mathrm{t}$ costs the INS $\$ 3,300$ to supervise each asylum seeker who appears for hearings compared to $\$ 7300$ for those detained." 75 Based on its research, the Vera Institute actually concluded that: "Asylum seekers do not need to be detained to appear for their hearings. They also do not seem to need intensive supervision."76

Another successful model is a project that was coordinated by the Lutheran Immigration and Refugee Service (LIRS). Through that project, the INS released twenty-five Chinese asylum seekers from detention in Ullin, Illinois, to shelters in several communities. The community shelters reminded participants of their hearings, scheduled checkins with the INS, organized transportation, and accompanied asylum seekers to their appointments. In addition, non-profit agencies also found pro bono attorneys for all of the asylum seekers who were released to the shelters. The project achieved a 96 per cent appearance rate. ${ }^{77}$
Despite these very successful models and the Vera Institute's finding that asylum seekers do not need to be detained, the U.S. government has not instituted a nationwide program of alternatives to detention for asylum seekers. While the U.S. Congress has allocated some resources (U.S. $\$ 3$ million) for alternatives to detention during fiscal 2002, as discussed below, it not clear to what extent, if any, those funds will be used to release from detention asylums seekers who would otherwise have been detained.

\section{Improving the Fairness of the U.S. Detention System}

The U.S. detention system for asylum seekers can be reformed to improve its fairness. Indeed, some concrete improvements are urgently needed as the current system is fundamentally unfair and fails to meet international standards. A number of critical changes are outlined below.

\section{- The decision to detain an asylum seeker should be} made by an appropriately trained adjudicator in an individualized proceeding.

At a very fundamental level, the premise of the U.S. detention system must change. The U.S. system is currently based on a requirement of "mandatory detention" for all arriving asylum seekers. A decision to detain should instead be made in an individualized proceeding, and detention should only be authorized in cases in which it has been demonstrated to be necessary.

Detention determinations should be made by trained adjudicators who have received specialized training in a range of areas including asylum law, country conditions, and special issues relating to survivors of torture. Other appropriate training would include training to assist in assessing asylum seekers' community ties and proof of identity. These adjudicators should be independent of both the INS and the Department of Justice, which are the detaining authorities.

In these proceedings, the asylum seeker should have the right to be represented and to present testimony and other evidence. Appropriate translation must be provided. If the INS believes that an individual should be detained, the INS should also have the opportunity to present evidence relevant to the detention determination.

- When parole is denied, an asylum seeker should have the opportunity to have that decision reviewed by an independent court.

When a request for parole is denied, the asylum seeker should have the opportunity to have that decision reviewed by a court that is independent of the detaining authority. This independent review is particularly important where the 
parole decision is made, as is currently the case in the U.S., by the detaining authority itself.

As an initial step, immigration judges should be authorized to review INS detention determinations relating to arriving asylum seekers. This reform is currently included in a bill, called the Refugee Protection Act, which has been introduced in both the U.S. Senate and the House of Representatives. ${ }^{78}$ The need for an independent adjudicator to make or review parole determinations has been stressed by a number of human rights organizations and by experts in the field. ${ }^{79}$

One of these experts has pointed out that in the U.S. criminal justice system, pre-trial release decisions are made by judges - and not by the enforcement-oriented prosecuting authority. Looking to the Bail Reform Act of 1984 as a model, Professor Michele Pistone has recommended that U.S. law be changed to take "authority over parole decision-making out of the hands of local districts and put it into the hands of neutral immigration judges ..."80

Ultimately, additional reforms - such as moving the immigration court system from the direct control of the Department of Justice - would be necessary to ensure the independence of immigration judges. The U.S. Commission on Immigration Reform and the National Association of Immigration Judges have both urged that immigration courts be removed from the Justice Department. ${ }^{81}$

- The criteria for detention and parole of asylum seekers should be spelled out in regulations.

Congress should direct the Justice Department to issue regulations providing for the release of asylum seekers who meet the "credible fear" standard, satisfy the identity and community ties criteria, and pose no danger to the community. The INS should not be permitted to issue only guidelines-rather than regulations-specifying the criteria for parole of asylum seekers, as this practice has repeatedly proven insufficient to ensure accountability and compliance by local INS districts. Experts who have monitored the implementation of the asylum parole guidelines have recommended just such an approach, and the Refugee Protection Act would require the Justice Department to issue regulations setting forth the criteria for paroling asylum seekers. ${ }^{82}$

\section{- A limit on the length of detention for asylum seekers} should be prescribed.

Some limits must be placed on the length of time that an asylum seeker may be detained while his or her asylum proceedings are pending. These limits could be established by regulation or by statute. Other countries have placed limits on the length of time that asylum seekers may be detained.$^{83}$ At the very least, a decision to detain an asylum seeker should be reviewed by an independent court on a regular basis. Asylum seekers who are detained for longer periods of time should be held in facilities that allow greater outdoor access, contact visits with family and friends, English classes and other educational opportunities.

\section{- The U.S. government should fund legal representation} for children and for indigent asylum seekers.

As detailed above, asylum seekers who are represented are more likely to win their cases. In turn, asylum seekers who are not represented (or are poorly represented) are sometimes detained for lengthy periods of time while they pursue their appeals.

While some European and other states provide funding for legal representation for asylum seekers, ${ }^{84}$ the U.S. does not. The funding options for non-governmental organizations that provide legal representation to asylum seekers are very limited. These organizations, given their lack of resources, cannot come close to meeting the substantial need for representation in asylum cases. While the U.S. government has just announced plans to provide some limited funding to conduct legal orientation presentations for asylum seekers, this effort, while commendable, will not meet the substantial need for legal representation in individual asylum cases. Government funding of legal representation would increase the number of individuals who win asylum at an early stage, and would decrease the number of appeals and the corresponding detention time leading to a savings of detention costs.

The U.S. government should fund representation for children in asylum and immigration proceedings. About half of the roughly five thousand children in INS detention are reportedly not represented. ${ }^{85}$ A bill, called the Unaccompanied Alien Child Protection Act, which would require that all unaccompanied children be provided with guardians ad litem and court-appointed lawyers to identify and defend their best interests, has been introduced in the U.S. Congress. ${ }^{86}$

- The U.S. government should devote significant resources to the advancement of alternatives to detention for asylum seekers.

While the U.S. Congress has allocated $\$ 3$ million for alternatives to detention during fiscal year 2002, it is not clear to what extent any projects initiated with those funds will be used to release from detention asylum seekers who would otherwise have been detained. Given the limited amount of funds, the INS would only be able to launch projects at a few locations. Some of these projects will likely be designed for immigration detainees who are not asylum seekers. In addi- 
tion, given the restrictive parole policies and resistance to outside involvement in parole determinations that have been evidenced by some INS districts that house significant numbers of detained asylum seekers, there is a chance that the INS will not make these projects available to the very asylum seekers who are most in need of them.

The U.S. Congress should continue to fund alternatives to detention, and should do so at a level that would ensure the availability of alternatives to detention across the country, rather than at just a few locations. Congress should also ensure that a significant amount of this funding is allocated to provide alternatives to detention to asylum seekers who would otherwise be detained.

- Asylum seekers should only be detained in appropriate facilities.

In the U.S., detained asylum seekers are held in large immigrations detention facilities and in local and county jails. Upon their arrival in the U.S. they are often handcuffed or shackled. Their clothes are taken from them. They are given prison uniforms to wear. Families are sometimes separated. Asylum seekers in some facilities are denied contact visits, even with young children. Asylum seekers have, over the years, reported abuse and mistreatment at some of these facilities.$^{87}$ In March 2002, Haitian women detained at a jail in Florida reported that they were not provided with adequate medical care. One woman reported that she woke up spitting blood every morning and had yet to see a doctor after three months in detention, and two pregnant women detainees had received no medical checks. ${ }^{88}$

Some asylum seekers have fled from torture or other traumatic experiences. Refugees often suffer from posttraumatic stress disorder, major depression, or other illnesses. ${ }^{89}$ As experts have emphasized, detention can exacerbate the suffering that these vulnerable individuals face. 90

When detention is used for asylum seekers, the conditions of detention should be appropriate for asylum seekers. Asylum seekers should not be held in criminal facilities. As asylum seekers are not criminals, when they are detained, they should generally be held in less restrictive settings, allowed to wear their own clothing, and given access to educational opportunities (such as English language classes) and, for those who are survivors of rape, torture, or other trauma, appropriate counselling.

\section{Conclusion}

The U.S. asylum detention system can be reformed. Reforming the system will require committed action by the U.S. Congress, the Department of Justice, and the INS itself. A major step towards reform would be the passage of the
Refugee Protection Act, a bill which would provide for immigration judge review of parole denials, the issuance of regulations specifying the parole criteria for asylum seekers, and the expanded use of alternatives to detention. The American public's increasing concern over the U.S. government's treatment of asylum seekers - as evidenced by the growing attention of religious leaders, the press, and other citizens across the country ${ }^{91}$ - will help to make reforms possible.

A central objective of these reforms must be to ensure that U.S. procedures are fundamentally fair. Only then can we ensure that those who flee to our shores seeking protection find the safety, freedom and fairness that are central to American values.

\section{Notes}

1. A refugee from Cameroon, statement submitted to the U.S. Senate, Immigration Subcommittee, Committee on the Judiciary (3 May 2001) on file with the Lawyers Committee for Human Rights.

2. Lawyers Committee for Human Rights, Refugees Behind Bars: The Imprisonment of Asylum Seekers in the Wake of the 1996 Immigration Act (New York: LCHR, 1999) at 19; online: $<$ http://www.lchr.org $>$.

3. D. Williams, "Macedonia Slows Flow of Incoming Refugees" The Washington Post (31 March 1999). ("Many refugees have reported that Yugoslav authorities are stripping them of their passports and other personal documents ...").

4. Immigration and Nationality Act (INA) § 235(b)(1)(B)(iii)(IV).

5. INA $\$ 235(\mathrm{~b})(1)(\mathrm{B})(\mathrm{v})$.

6. E. Shmitt, "When Asylum Requests Are Overlooked" The New York Times (15 August 15 2001) A6; J. M. Gonzalez, "Amityville Woman Seeks \$8Million in JFK Mix-up” Newsday (12 July 2000).

7. Ibid; The Expedited Removal Study, "Report on the First Three Years of Implementation of Expedited Removal” (San Francisco: University of California, Hastings College of Law, 2000), online: <http://www.uchastings.edu/ers/>; Lawyers Committee for Human Rights, Is This America? The Denial of Due Process to Asylum Seekers in the United States (2000).

8. Supra note 4; INA Section 212(d)(5)(A) (providing for parole "on a case-by-case basis for urgent humanitarian reasons or significant public benefit" for an alien applying for admission); 8 Code of Federal Regulations (C.F.R.) \$ 235.3(c); 8 C.F.R. $\$ 212.5(\mathrm{a})$; Memorandum from Office of INS Deputy Commissioner, "Implementation of Expedited Removal," (31 March 1997), reprinted in 74 Interpreter Releases (21 April 1997) (“[o]nce an alien has established a credible fear of persecution or is otherwise referred (as provided by regulation) for a full removal proceeding under section 240, release of the alien may be considered under normal parole criteria") (1997 INS Guidelines).

9. 8 C.F.R. $\$ 3.19$. 
10. 8 C.F.R. $\$ 3.19(\mathrm{~h})(2)(\mathrm{i})(\mathrm{B})$.

11. 1997 INS Guidelines, supra note 8.

12. Memorandum from G. McNary, INS Commissioner, "Pilot Parole Project for Aliens Seeking Asylum in Exclusion Proceeding," (27 April 1990); Memorandum from G. McNary, INS Commissioner, "Parole Project for Asylum Seekers at Ports of Entry and in INS Detention" (20 April 1992); Lawyers Committee for Human Rights, Interim Report on the Pilot Parole Project of the Immigration and Naturalization Service (New York: 1990).

13. Memorandum from INS Executive Associate Commissioner for Field Operations, Detention Guidelines Effective October 9, 1998, 75 Interpreter Releases 1523 (2 November 1998) (emphasis added) (1998 INS Guidelines).

14. Petition to the INS, EOIR, DOJ, Seeking a Rule on Procedures for Parole of Detained Asylum Seekers, submitted by the Lawyers Committee for Human Rights, January 1996.

15. L. Getter, "Freedom Elusive for Refugees Fleeing to the U.S." Los Angeles Times (31 December 2001); F. N. Tulsky, "Uncertain Refuge: Asylum Seekers Face Tougher U.S. Laws, Attitudes" San Jose Mercury New, (10 December 2000); M. Ohito, "Inconsistency at INS" The New York Times (22 June 1998); T. Beach \& P. Yost, "INS Jailing Many Asylum Seekers" The Boston Globe (17 November 1998) A27; see also Human Rights Watch, Locked Away: Immigration Detainees in Jails in the United States (September 1998); Lawyers Committee for $\mathrm{Hu}-$ man Rights, Refugees Behind Bars, supra note 1; Women's Commission for Refugee Women and Children, Forgotten Prisoners: A Follow-Up Report on Refugee Women Incarcerated in York County, Pennsylvania (July 1998).

16. 65 Fed. Reg. 82254-82256, "Clarification of Parole Authority" (INS No. 2004-9965) (28 December 2000).

17. Ibid. (the change was needed because "[s]ome have interpreted Sec. 212.5 [the relevant parole regulation] to mean that the authority to grant parole is limited to the DD [district director] and the CPA [chief patrol agent].").

18. D. Mallone, "851 Detained for Years in INS Centers - Many Are Pursuing Asylum,” Dallas Morning News (1 April 2001); U.S. National Council of Churches, Press Release, "People Fleeing from Persecution Held in Worse Than Prison Conditions in the U.S." (20 April 20 2001), online: $<$ http://www.ncccusa.org/news/ 01news38.html>; Testimony of Bishop T. G. Wenski on behalf of National Conference of Catholic Bishops Committee on Migration, before the House Judiciary Subcommittee on Immigration and Claims (15 May 2001).

19. FY 1999 Omnibus Consolidated and Emergency Supplemental Appropriations Act (Public Law 105-277), \$\$ 903-4; supra notte 15, F. N. Tulsky, "Asylum seekers face tougher U.S. Laws, attitudes" (INS lacks precise data on detained asylum seekers; regarding failure to comply with statute requiring that INS report data: "An INS spokesman said that complying with the law would drain resources from other mandated responsibilities.").
20. See supra note 15; "Detainees held in prison-like conditions," Ecumenical News International (June 2001), online: $<\mathrm{http} / / /$ www.dfms.org/episcopal-life/Detainee.html>.

21. Supra note 2, at 6-7 (Somali asylum seeker detained for 4 years before being granted asylum); M. Clancy, "Nigerian Finally Wins Asylum After Long Fight" The Herald News (20 July 20 2001) (Nigerian refugee granted asylum after 3 years and 4 months in detention); D. Malone, "Man Locked up for Four Years but Convicted of Nothing" The Dallas Morning New, (1 April 1 2001) (Sri Lankan asylum seeker detained for four years); C. Hedges, "Immigrant Detained for 3 and 1/2 years Emerges from Labyrinth," The New York Times (6 November 2000) (Congolese refugee granted asylum after three and onehalf years in jails and detention facilities); B. Walth, "Asylum Seekers Greeted With Jail," The Oregonian (10-15 December 2001 (Liberian asylum seeker detained for six years, Chinese asylum seeker detained over two years, Sri Lankan asylum seeker detained for four years).

22. D. Mallone, "851 Detained for Years in INS Centers - Many Are Pursuing Asylum” The Dallas Morning News (1 April 2001).

23. F. N. Tulsky, "Asylum Seekers Face Tougher US Laws, Attitudes" San Jose Mercury News (10 December 2000.

24. A. Elsner, "Congressmen Protest INS Treatment of Retarded Boy," Reuters, (27 March 2002); and articles referenced in notes 25 to 27 infra.

25. E. Herman, "Immigration: No Kid Gloves," The New York Daily News (30 April 2000).

26. Ibid.; E. Amon, "Access Denied, Children in INS Custody Have No Right to a Lawyer" The National Law Journal (12 April 2001).

27. A. Elsner, "New York Dentists Can Settle Fate of Migrants" Reuters (11 January 2002); C. Hedges, "Crucial INS Gatekeeper: The Airport Dentist" The New York Times (22 July 2001).

28. M. R. Pistone and P. G. Schrag, "The New Asylum Rule: Improved but Still Unfair" (Fall 2001) 16 Georgetown Immigration Law Journal 49, n. 272 \& n. 273 (citing numerous medical reports, including: N. R. Holtan, Survivors of Torture (1999) 114 Pub. Health Rep. 489; D. Silove, et al., "Anxiety, Depression and PTSD in Asylum-Seekers: Associations With Pre-Migration Trauma and Post-Migration Stressors" (1997) 170 British J. Psychiatry 351, 351-57; H. Thulesium and A. Hakansson, "Brief Report: Screening for Posstraumatic Stress Disorder Symptoms Among Bosnian Refugees" (1999) $12 \mathrm{~J}$. Traumatic Stress 167, 171-73).

29. E. Llorente, "Dreams Turn to Despair" The Bergen County Record (24 May 1999) (quoting Dr. Beverly Pincus, director of Cross-Cultural Counseling Center at the International Institute of New Jersey).

30. B. Walth, "Asylum Seekers Greeted with Jail" The Oregonian (10-15 December 2001); Vera Institute of Justice, Testing Community Supervision for the INS: An Evaluation of the Appearance Assistance Program (August 2000) vol. 1 at 66. 
31. 67 Fed. Reg. 7309-7318, "Board of Immigration Appeals: Procedural Reforms to Improve Case Management" (19 February 2002).

32. American Immigration Law Foundation News, Volume 4, Issue 3, March 2002, available online at $<$ http://www.ailf.org >; see Comments filed by Capitol Area Immigrants Rights Coalition (CAIR) and Comments filed by the Lawyers Committee for Human Rights [on file with the author].

33. "Joint Statement on Cooperation on Border Security and Regional Migration Issues" issued by the U.S. and Canada (3 December 2001); D. L. Brown, "U.S., Canada to Sign Border Accord" Washington Post Foreign Service (4 December 2001) A16.

34. See B. Frelick, "Who's On First? The Canada-U.S. Memorandum of Agreement on Asylum" (26 February 1996) 73 Interpreter Releases 217.

35. 66 Fed. Reg. 48334, INS No. 2171-01, "Custody Procedures," Sept. 20, 2001. The regulation does not limit this power to high level officials; it could allow individual INS officers to decide whether there is an "extraordinary" or "emergency" situation.

36. 66 Fed. Reg. 54909, "Automatic Stay of Bond Orders of Immigration Judges” (31 October 2001).

37. Amnesty International, Amnesty International's Concerns Regarding post September 11 detentions in the USA (March 2002) (AI Index: AMR 51/044/2002); J. Edwards, “Attorneys Face Hidden Hurdles" New Jersey Law Journal (3 December 2001).

38. J. A. Benjamin, "Iraqi Refugees Cleared by FBI Could Still Face Deportation" South Florida Sun-Sentinel (12 December 2001).

39. Memorandum from M. D. Cronin, INS Executive Associate Commissioner, "Deferred Inspection, Parole and Waivers of Documentary Requirements," 1(4 November 2001), reprinted in 79 Interpreter Releases 49 (7 January 2002).

40. R. A. Serrano, "Ashcroft Denies Wide Detainee Abuse" Los Angeles Times (17 October 17 2001); R. A. Serrano, "Judge Denies Young Iraqi's Bid to Join Family" Los Angeles Times (14 January 2002); A. Viglucci and A. Chardy, "Iraqi Christians Get Caught up in Security Web" Miami Herald (26 December 2001); J. Benjamin, "Mideast Detainees Await Freedom," The South Florida Sun-Sentinel (8 December 2001).

41. Editorial, "Justice Denied, Again for Haitian Asylum Seekers," Miami Herald (18 March 2002); J. Benjamin, "INS Admits New Get-Tough Policy on Haitians Aimed at Preventing Exodus," South Florida Sun-Sentinel (20 March 2002); A. Chardy, "INS Clamps Down on Haitian Asylum-Seekers" Miami Herald (20 March 2002).

42. INA $\$ 208(\mathrm{~d})(5)(\mathrm{A})(\mathrm{i})$.

43. INA $\$ 208(\mathrm{~b})(2)$.

44. 8 C.F.R. $\$ 212.5(\mathrm{a})$ (prohibiting parole of anyone who is a security risk). The 1997 INS Guidelines, supra note 8, specify that parole is only a viable option for asylum seekers who meet certain criteria and "are not subject to any possible bars to asylum involving violence or misconduct." The 1997 INS Guidelines detail procedures to be followed if some concern arises that an individual may be a security risk, may be subject to a terrorist bar or may otherwise be a danger to the community. These procedures include an investigation and inquiries to the FBI and other appropriate agencies. The 1998 INS Guidelines, supra note 13, provide that "it is INS policy to favor release of aliens found to have a credible fear of persecution, provided that they do not pose a risk of flight or danger to the community" [emphasis added].

45. D. Williams, "Macedonia Slows Flow of Incoming Refugees" The Washington Post (31 March 31 1999) ("Many refugees have reported that Yugoslav authorities are stripping them of their passports and other personal documents ....); The American Jewish Committee Office of Government and International Relations, News Release, "American Jewish Committee Speaks at Capitol Urging Rollback of Harsh Immigration Legislation" (17 September 1999) ("Often those fleeing repressive regimes have no means of escape except by using invalid travel documents. It should be recalled that this nation has long honored Raoul Wallenberg, who saved countless lives during the Holocaust by issuing unofficial travel documents.")

46. Supra note 2 , at 7 .

47. For instance, the Lawyers Committee is aware of a number of asylum seekers who fled to the U.S. on their own valid passports and on visas that were originally obtained for legitimate reasons but were detained under expedited removal after they explained to INS officials at the airport that they wished to apply for asylum.

48. Article 31, United Nations Convention Relating to the Status of Refugees, 28 July 1951, 189 U.N.T.S. 150 (entered into force 22 April 1954) [hereinafter Refugee Convention]. The U.S. became bound by Articles 2-34 of the Convention when, in 1968, it acceded to the United Nations Protocol Relating to the Status of Refugees, 31 January 1967, 19 U.S.T. 6223, 60 U.N.T.S. 267 (1968) (entered into force October 4, 1967, accession by the United States in 1968) [hereinafter Protocol]. For a detailed discussion of the scope and meaning of Article 31 of the Refugee Convention, see G. S. Goodwin-Gill, “Article 31 of the 1951 Convention relating to the Status of Refugees: Non-penalization, Detention and Protection," October 2001 (prepared at the request of UNHCR for the Global Consultations), online: <http://www.unhcr.ch $>$.

49. United Nations High Commissioner for Refugees, UNHCR Revised Guidelines on Applicable Criteria and Standards relating to the Detention of Asylum Seekers, February 1999, online: $<$ http://www.unhcr $>$ at 3 [hereinafter UNHCR Detention Guidelines]; UNHCR Executive Committee Conclusion on Detention of Refugees and Asylum Seekers, No. 44 (1986).

50. 1997 INS Guidelines, supra note 8; 1998 INS Guidelines, supra note 13.

51. See note 15 supra.

52. E. Llorente, "Dreams Turn to Despair" The Bergen County Record ( 24 May 1999) (quoting New Jersey District Director); Lawyers Committee for Human Rights, Refugees Behind Bars at 29 n.96 (reporting statistics).

53. A. Elsner, "Haitian Women Asylum Seekers Complain about US Prison" Reuters (14 March 2002); National Coalition for 
Haitian Rights, Press Release, "Haitian Coalition Urges the Release of over 200 Haitian Asylum Seekers in Miami," (8 March 2002); A. Chardy, "INS Clamps Down on Haitian Asylum-Seekers" Miami Herald (20 March 2002).

54. E. Ebrahimian, Lutheran Immigration and Refugee Services, "Senate Committee Votes to Fund Legal Orientations and Detention Alternatives" Detention Watch Network News, Issue 18 (Summer 2001). See also M.-L. Hopgood, "Immigrant Detention under Fire" Dayton Daily News (13 August 13 2001). Chen was only released after human rights and refugee advocacy organizations raised her case with the press and with INS headquarters. She was subsequently granted asylum.

55. International Covenant on Civil and Political Rights, 19 December 1966, 999 U.N.T.S. 171, art. 9(1) (entered into force 23 March 1976, accession by the United States 8 June 1992) [hereinafter ICCPR].

56. M. R. Pistone, “Justice Delayed Is Justice Denied” (1999) 12 Harvard Human Rights Journal 197 at 247.

57. See notes 9-10 supra and accompanying text. Federal court habeas petitions have not proved an effective tool for review of parole denials. Not only does it often take months or longer for federal courts to make decisions, but federal courts have in some cases refused to review INS parole determinations in the wake of the 1996 law, and in other cases have deferred to INS parole determinations as long as the INS cites a reason for its parole denial. See Veerikathy v INS, 98 Civ. 2591, 1998 U.S. Dist. LEXIS 19360 (E.D.N.Y. Oct. 9, 1998); see also Bertrand v. Sava 684 F.2d 204 (2d Cir. 1982); Zhang v. Slattery, 840 F. Supp. 292 (S.D.N.Y. 1994).

58. ICCPR, art. 9(4).

59. See United Nations Human Rights Committee, General Comment 8/16 ("the important guarantee laid down in paragraph 4 [of article 9], i.e. the right to court control of the legality of detention, applies to all persons deprived of their liberty by arrest or detention."); United Nations Commission on $\mathrm{Hu}-$ man Rights, resolution 1997/50, Commission on Human Rights, UN doc. E/CN.4/RES/1997/50, 15 April 1997 (requesting that Working Group on Arbitrary Detention "devote all necessary attention to reports concerning the situation of immigrants and asylum seekers who are allegedly being held in prolonged administrative custody without the possibility of administrative or judicial remedy ....”).

60. Torres v. Finland, UN Human Rights Committee, Communication No. 291/1988, 2 April 1990 (concluding that asylum seeker's detention during period in which he was unable to appeal detention order to court violated ICCPPR Article 9(4)).

61. A v. Australia, UN Human Rights Committee, Communication No. 560/1993, 3 April 1997 (finding that a court review, which was limited to a finding that the asylum seeker was indeed a "designated person" within the meaning of Australia's Migration Amendment Act did not satisfy the requirements of Article 9, paragraph 4, of the ICCPR).

62. UNHCR Detention Guidelines, supra note 49; see also UNHCR Executive Committee Conclusion 44 (1986) ("de- tention measures taken in respect of refugees or asylum seekers should be subject to judicial or administrative review.").

63. See note 21 supra and accompanying text.

64. Zadvydas v. Davis, 533 U.S. 678, 121 S. Ct.249 (2001).

65. "After this 6-month period, once the alien provides good reason to believe that there is no significant likelihood of removal in the reasonably foreseeable future, the Government must respond with evidence sufficient to rebut that showing. And for detention to remain reasonable, as the period of prior post-removal confinement grows, what counts as the reasonably foreseeable future conversely would have to shrink. This 6-month presumption, of course, does not mean that every alien not removed must be released after six months. To the contrary, an alien may be held in confinement until it has been determined that there is no significant likelihood of removal in the reasonably foreseeable future." Zadvydas, 533 U.S. at 701.

66. See, e.g., K. Coffey, "The Due Process Right to Seek Asylum in the United States: The Immigration Dilemma and Constitutional Controversy" (2001) 19 Yale Law and Policy Review 303; Brief Amicus Curiae of the Lawyers Committee for Human Rights to the U.S. Supreme, Reno v. Ma, 26 December 2000. (The Supreme Court consolidated the Ma and Zadvydas cases.)

67. 66 Fed. Reg. 56967 - 56982, "Continued Detention of Aliens Subject to Final Orders of Removal," 14 November 2001 (excluding arriving aliens from regulations issued pursuant to Zadvydas decision).

68. A v. Australia, supra note 61.

69. UN Working Group on Arbitrary Detention, Deliberation No. 5, Principle 7, UN doc. E/CN.4/2000/4, 28 December 1999, Annex II.

70. "Asylum Representation, Summary Statistics" prepared by Dr. Andrew I. Schoenholtz, Director of Law and Policy Studies, Institute for the Study of International Migration, Georgetown University, May 2000.

71. See Pistone, "Justice Delayed," supra note 56 at 218 ("Being in detention frustrates asylum seekers' ability to work efficiently with their representatives. Detained asylum seekers are not able to locate witnesses, gather evidence, or otherwise assist their attorneys in case preparation.")

72. Ibid., at 219-20.

73. Ibid., at 2 .

74. Vera Institute of Justice, Testing Community Supervision for the INS: An Evaluation of the Appearance Assistance Program, vol. 1, pp iii, 8, 27 (August 2000), online: <http://www.vera.org>; C. Stone, "Supervised Release as an Alternative to Detention in Removal Proceedings: Some Promising Results of a Demonstration Project" (2000) Georgetown Immigration Law Journal at 283, 285.

75. Ibid., Vera Institute, at iii.

76. Ibid., Vera Institute, at 31 .

77. E. Ebrahimian, "The Ullin 22: Shelters and Legal Service Providers Offer Viable Alternatives to Detention," Detention Watch Network News, August/September 2000, at \#8. 
78. Refugee Protection Act (S1311, H4074), test available online: $<$ http://www.lchr.org>; F. Trejo, "Senators Propose Bill to Ease Provisions for Asylum Seekers" The Dallas Morning News (3 August 3 2001).

79. See, e.g., Lawyers Committee for Human Rights, Refugees Behind Bars, supra note 2 at 3; Women's Commission for Refugee Women and Children, Behind Locked Doors: Abuse of Refugee Women at the Krome Detention Center, October 2000; Human Rights Watch, Locked Away: Immigration Detainees in Jails in the United States (September 1998) at 7; F. N. Tulsky, "Uncertain Refuge: Asylum Seekers Face Tougher U.S. Laws, Attitudes" The San Jose Mercury News (10 December 2000) (quoting recommendation of T. Alexander Aleinikoff, expert on immigration law and former INS Associate Commissioner for Programs); M. Pistone, Harvard Human Rights Journal, supra note 56.

80. M. R. Pistone, "Justice Delayed Is Justice Denied: Proposal for Ending the Unnecessary Detention of Asylum Seekers" (Spring 1999) Harvard Human Rights Journalat 56.

81. S. McRae, "Judges Pursue New Level of Independence" Daily Journal Newswire (17 January 2002), online: $<$ http://www.dailyjournal.com $>$.

82. A. C. Helton, "A Rational Release Policy for Refugees: Reinvigorating the APSO Program," 75 Interpreter Releases No. 19 (May 18, 1998) ("The Department of Justice should engage in rulemaking to embody [APSO asylum parole] program criteria and procedures in regulation."); Lawyers Committee for Human Rights, Petition for Rulemaking, note 14 supra. The text of the proposed Refugee Protection Act is available at $<$ http://www.LCHR.org $>$.

83. G. Goodwin-Gill, Article 31, supra note 48 at $24 \mathrm{ff}$ (discussing practices of various states).

84. The United Kingdom, Ireland, Denmark and some other European states provide some funding for legal representation of asylum seekers. The Australian government also funds some legal representation for asylum seekers.

85. E. Amon, The National Law Journal, supra note 26.

86. Unaccompanied Alien Child Protection Act of 2001, S 121 (HR1904). The text of the bill and additional information relating to the bill are available at $<\mathrm{http}$ /www.lirs.org $>$.

87. Human Rights Watch, Locked Away, supra note 79; Lawyers Committee for Human Rights, Refugees Behind Bars, supra note 2.

88. A. Elsner, "Haitian Women," Reuters (14 March 2002).

89. Pistone \& Schrag, The New Asylum Rule, supra note 28.

90. See note 29 supra and accompanying text.

91. E. Ibrahimian, Lutheran Immigration and Refugee Service, "Religious Leaders Decry Detention Conditions and Call for Changes" Detention Watch Network Newsletter, Summer 2001; Bishop Nicholas DiMarzio, Chairman of the U.S. Catholic Bishops' Committee on Migration, "Liberty (But Not) For All” The Newark Star Ledger (24 May 2001); L. S. Glickman, President of the Hebrew Immigrant Aid Society, The Bergen County Record (10 July 2001).
Eleanor Acer is the Director of the Asylum Program at the Lawyers Committee for Human Rights. She oversees the Lawyers Committee's pro bono asylum representation program, which provides hundreds of indigent refugees with volunteer legal representation every year, and advocates for the rights of refugees. She writes and speaks regularly on a range of refugee issues, including the detention of asylum seekers.

(C) Eleanor Acer, 2002. This open-access work is licensed under a Creative Commons Attribution-NonCommercial 4.0 International License, which permits use, reproduction and distribution in any medium for non-commercial purposes, provided the original author(s) are credited and the original publication in Refuge: Canada's Journal on Refugees is cited. 